\title{
Not in My Name! Claudia Pechstein and the Post-Consensual Foundations of the Court of Arbitration for Sport
}

\author{
Antoine Duval"
}

"In whose name?" do international courts adjudicate is the fundamental question posed by Armin von Bogdandy and Ingo Venzke. ${ }^{1}$ In the present chapter, I aim to transpose some of their reflections to the context of the Court of Arbitration for Sport (CAS). To illustrate the suitability of this transposition, I will focus on the decisions rendered by the Landgericht (LG) and the Oberlandesgericht (OLG) München and by the Bundesgerichtshof $(\mathrm{BGH})$ in a highly publicized dispute involving Claudia Pechstein, a famous German speed-skater and Olympic champion. ${ }^{2}$ The case will now potentially move to the Bundesverfassungsgericht.

Von Bogdandy and Venzke's first fundamental claim is that international courts are multifunctional. By that they mean that international courts "transcend the one-dimensional fixation on dispute settlement" They argue that courts also stabilize normative expectations, are instruments of lawmaking, and a means to control and legitimize public authority. ${ }^{4}$ Additionally, they suggest that international courts exercise international public authority. They define public authority as "the ability, grounded in law, to restrict the freedom of other actors, or to shape their

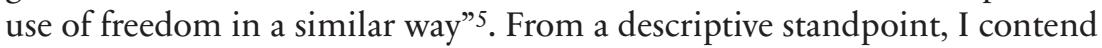

* Senior Researcher, Asser Institute - Institute for International \& European Law.

1 Von Bogdandy, A. and Venzke, I. (2014), In Whose Name? A Public Law Theory of International Adjudication. Oxford: Oxford University Press. See also the shorter version of their argument in: Von Bogdandy, A. and Venzke, I. (2012), "In Whose Name? An Investigation of International Courts' Public Authority and Its Democratic Justification”, European Journal of International Law 23(1), 7-41.

2 BGH, Urteil v. 7. Juni 2016- KZR 6/15 http://juris.bundesgerichtshof.de/cgi-bin/rec htsprechung/document.py?Gericht=bgh\&Art=en \&nr=75021\&pos=0\&anz=1, accessed 21 February 2020.

3 Von Bogdandy and Venzke (2014), supra note 1, 5.

4 Ibid., 10-16.

5 Ibid., 17. On their understanding of authority, see also: Venzke, I. (2013), "Between Power and Persuasion: On International Institutions' Authority in Making Law”, Transnational Legal Theory 4(3), 354-373; von Bogdandy and Venzke (2012), supra note 1 . 
that the CAS can also be qualified as a multifunctional Court exercising international public authority. ${ }^{6}$ CAS awards are embedded in a wide network of decisions constituting a specific jurisprudence and contributing to the stabilization of normative expectations in the global sporting field. ${ }^{7}$ The CAS also engages in judicial lawmaking via its recourse to general principles and has become an important institutional avenue to control and challenge the exercise of international public authority by the Sports Governing bodies (SGBs). ${ }^{8}$ Finally, its decisions affect the life of thousands of athletes, clubs and fans around the world. ${ }^{9}$ The question is then how to legitimize this exercise of international public authority. As pointed out by von Bogdandy and Venzke, the "traditional understanding" 10 is that it is the consensus of the (states or private) parties that justifies the exercise of public authority by international courts. But, in whose name does the CAS operate? The automatic answer from a private international law perspective must be: in the name of the parties. This chapter will show that this conventional wisdom is challenged in practice. In fact, Claudia Pechstein's loudly resonating (and convincing) answer to this same question is: Not in my name!

I aim to show in the first part of this article that she is right to consider that her free consent cannot be a credible foundation for CAS arbitration. Nonetheless, I will discuss in the second part other, more or less persuasive, names which can be (and have been) invoked to support the legitimacy of post-consensual CAS arbitration.

6 For a similar claim, see Casini, L. (2011), "The Making of a Lex Sportiva by the Court of Arbitration for Sport", German Law Journal 12(5), 1317-1340.

7 Discussing the emergence of a CAS jurisprudence, see: Kaufmann-Kohler, G. (2007), "Arbitral Precedent: Dream, Necessity or Excuse?", Arbitration International 23(1), 357-378; Maisonneuve, M. (2011), L'arbitrage des litiges sportifs. Paris: L.G.D.J, 443-477.

8 See Latty, F. (2007), La Lex sportiva: recherche sur le droit transnational. Leiden/ Boston: Martinus Nijhoff; and Casini, supra note 6.

9 On the concept of lex sportiva and the role of the CAS, see Latty, supra note 8; and Duval, A. (2013), "Lex sportiva: a playground for transnational law", European Law Journal 19(6), 822-842.

10 Von Bogdandy \& Venzke (2014), supra note 1, 18. 


\section{Not in my name! Why CAS does not speak in the name of Claudia} Pechstein

Von Bogdandy and Venzke's overture to their book reformulated to match this case study would read as follows: viewed in light of an important and still dominant understanding of private international law, international arbitration tribunals are mere instruments of dispute settlement whose activities are justified by the consent of the parties that created them and in whose name they decide. ${ }^{11}$ The post-consensual shift openly discussed in public international law ${ }^{12}$ remains a taboo as far as international arbitration is concerned. ${ }^{13}$ As one of the most prominent international (and CAS) arbitrators, Jan Paulsson, has put it: "The idea of arbitration is that of binding resolution of disputes accepted with serenity by those who bear its consequences because of their special trust in chosen decision-makers."14

It is a natural assumption: CAS jurisdiction must be grounded in the "serene" consent of the parties. As this chapter will show, this apparent truism does not hold in practice, as the LG and OLG München acknowledged in their respective rulings in the Pechstein case.

11 The original quote reads: "Viewed in light of an important and once even dominant understanding of international law, international courts are mere instruments of dispute settlement whose activities are justified by the consent of the states that created them and in whose name they decide". Ibid.,1.

12 On this shift, see Romano, C. (2007), "The Shift from the Consensual to the Compulsory Paradigm in International Adjudication: Elements for a Theory of Consent", New York University Journal of International Law \& Politics 39(4), 791872. See also the discussion in Von Bogdandy and Venzke (2014), supra note 1, 3.

13 A slowly cracking taboo as some recent $\mathrm{PhD}$ theses are tackling the issue, see Diallo, O. (2010), Le consentement des parties à l'arbitrage international. Paris: L.G.D.J.; Steingruber, A.-M. (2012), Consent in International Arbitration. Oxford: Oxford University Press.

14 The quote continues: "It is difficult for courts to achieve this kind of acceptance; public justice tends to be distant and impersonal. Arbitration is a private initiative. It does not ask that ordinary citizens struggle with Rousseau or Locke or other philosophers' abstractions of a general 'social contract', lacking any mooring in time and space, which might otherwise be enlisted to justify law's dominion. The ideal of arbitration is freedom reconciled with law”. Paulsson, J. (2013), The Idea of Arbitration. Oxford: Oxford University Press, 1. 


\section{A. Free consent as foundation for the CAS}

The CAS and the Swiss Federal Tribunal (SFT) attempt to keep alive the consensual myth that must, in principle, underlie CAS arbitration.

\section{The roots of the consensual myth}

In the eyes of a majority of arbitration scholars, consent is the sine qua non requirement, the "cornerstone" 15 , delimiting the reach of the conceptual territory of the notion of arbitration. ${ }^{16}$ Forced arbitration is at the "antipodes" 17 of the traditional understanding of arbitration. It is thus very understandable that the literature, the CAS and the SFT have had extreme difficulties in parting with this foundation. For many, the CAS is simply an "arbitration tribunal whose jurisdiction and authority are based on agreement of the parties"18. Indeed, "[s]ports arbitrations only exist because the athlete, the national governing body, and others in the sport world have agreed to be bound by arbitration and the outcome of the case" ${ }^{19}$. Hence, the jurisdiction of the CAS is perceived as "voluntary" 20 and the parties' consent as "paramount" 21 . It is just common sense, "[a]s with any arbitration $[\ldots]$ the disputing parties must consent to have their dispute resolved

15 Rigozzi, A. and Robert-Tissot, F. (2012), "La pertinence du 'consentement' dans l'arbitrage du Tribunal Arbitral du Sport”, Jusletter, 16 July, 2.

16 Jarrosson, C. (2001), "Les frontières de l'arbitrage", Revue de l'Arbitrage (1), 5-41, 19-20.

17 "Le forçage est tellement aux antipodes de la conception communément admise de l'arbitrage, assis sur des bases conventionnelles, qu'il paraît impossible de parler d'arbitrage forcé." Pinna, A. (2008), "Réflexions sur l'arbitrage forcé”, Gazette du Palais (351), 14-16 December, 6.

18 Mitten, M.J. and Opie, H. (2010), "Sports Law: Implications for the development of International Comparative and National law and Global Dispute Resolution", Tulane Law Review 85(2), 269-322, 285.

19 McLaren, R.H. (2001), "The Court of Arbitration for Sport: An Independent Arena for the World's Sports Disputes”, Valparaiso University Law Review 35(2/3), 379-405, 382.

20 Ansley, C. (1995), "International Athletic Dispute Resolution: Tarnishing the Olympic Dream", Arizona Journal of International and Comparative Law 12(1), 277 302, 298.

21 Reilly, L. (2012), "An Introduction to the Court of Arbitration for Sport (CAS) \& the Role of National Courts in International Sports Disputes", Journal of Dispute Resolution 5(1), 63-81, 66. 
by an arbitration administered by the CAS"22. Even when this foundation is characterized as "highly unusual", it is nevertheless deemed as having "consensual origin".23

The CAS Code ${ }^{24}$ has been feeding this consensual myth, as its Article R27 indicates that: "These Procedural Rules apply whenever the parties have agreed to refer a sports- related dispute to CAS. Such reference may arise out of an arbitration clause contained in a contract or regulations or by reason of a later arbitration agreement (ordinary arbitration proceedings) or may involve an appeal against a decision rendered by a federation, association or sports-related body where the statutes or regulations of such bodies, or a specific agreement provide for an appeal to CAS (appeal arbitration proceedings)."

The official commentary of the CAS Code indicates under this provision that " $[\mathrm{t}]$ he basic requirement for CAS arbitration is the parties' agreement to arbitrate, which includes an offer to arbitrate and an acceptance thereof" 25 . The agreement, or consent, of the parties is clearly seen as the trigger of the jurisdiction of the CAS. Furthermore, Article 178 of the Swiss Statute for Private International Law (PILA) provides the conditions of validity of an arbitration agreement in international arbitration seated in Switzerland. Two main requirements need to be fulfilled:

1. The arbitration agreement must be made in writing, by telegram, telex, telecopier or any other means of communication which permits it to be evidenced by a text.

2. Furthermore, an arbitration agreement is valid if it conforms either to the law chosen by the parties, or to the law governing the subject-matter of the dispute, in particular the main contract, or to Swiss law.

It is important to keep in mind that the validity of the agreement needs to be recognized either by the law chosen by the parties, the law governing the subject matter of the dispute or Swiss law. The Swiss Federal tribunal has held that under Swiss law, "it is to be understood as an agreement by

22 Coccia, M. (2003), "International Sports Justice: The Court of Arbitration for Sport”, European Sports Law and Policy Bulletin (1), 23-76, 34.

23 Paulsson, J. (1993), "Arbitration of International Sports Disputes", Arbitration International 9(4), 359-370, 369.

24 The latest version of the Code is available at http:/www.tas-cas.org/fileadmin/user _upload/Code_2017_FINALen_.pdf, accessed 1 February 2017.

25 Mavromati, D. and Reeb, M. (2015), The Code of the Court of Arbitration for Sport. Commentary, Cases and Materials. Alphen aan den Rijn: Wolters Kluwer International, 33. 
which two or more determined or determinable parties agree to submit one or several existing or future determined disputes bindingly to an arbitral tribunal and to the exclusion of the original state jurisdiction according to a legal order immediately or indirectly determined" 26 . This implies that "[b]eing a contract, the arbitration agreement is effective when the parties displayed their willingness to resort to arbitration reciprocally and in a concordant manner" 27 . Thus, "waiving the legal protection provided by the state is not done lightly, but is the result of a well-established desire to do so" 28 .

In short, the prevalent state of mind as stated by a CAS panel discussing its jurisdiction is that: "Arts. R27 and R47 of the CAS Code state the obvious with respect to jurisdiction: A court of arbitration has jurisdiction only if the parties to a dispute have made an agreement to that effect." 29

This has led the CAS and the SFT to develop specific legal strategies to circumvent the thinness of the consensual foundation of the agreement to arbitrate a sporting dispute at the CAS. ${ }^{30}$

\section{Keeping the consensual myth alive: The legal strategies of the CAS and the SFT}

The main legal strategy used by both the CAS and the SFT to uphold the validity of forced arbitration agreements in favour of the CAS, has been to deny any relevance of the free will of the athletes/clubs and to focus instead on the existence of a CAS arbitration agreement in a written document (the entry form to the Olympics for example) or in statutes and regulations

26 A. v. Trabzonspor Kulübü Dernegi \& Turkish Football Federation (TFF), SFT Case 4A_404/2010, Judgment of 19 April 2011, para. 4.2.2. Where not otherwise indicated we use the English translations of the SFT's judgments available at http://w ww.swissarbitrationdecisions.com/, accessed 1 February 2017.

27 Egyptian Football Association v. Al-Masry Sporting Club, SFT Case 4A_682/2012, Judgment of 20 June 2013, para. 4.4.1.

28 Nagel v. Fédération Equestre Internationale, SFT Case 4C_44/1996, Judgment of 31 October 1996, para. 2. The English translation used is the one provided in Reeb, M. (ed.) (1998), Digest of CAS Awards 1986-1998. Alphen aan den Rijn: Kluwer, 585-592.

29 Telecom Egypt Club v. Egyptian Football Association (EFA), CAS case 2009/A/1910, award of 9 September 2010, para. 6.

30 This article focuses on arbitration between SGBs and athletes/clubs through the CAS appeal procedure. The CAS ordinary procedure features disputes usually grounded on a classical consensual agreement between two private parties. 
to which a written document signed by an athlete refers. ${ }^{31}$ The latter option, the so-called arbitration agreement by reference, ${ }^{32}$ is the most popular as it requires only a global reference to the rules and regulations of an SGB to be deemed valid. The SFT has repeatedly condoned this legal construct, chiefly in the Nagel ${ }^{33}$ and Roberts ${ }^{34}$ cases.

The Nagel case involved a rider contesting an anti-doping sanction imposed by the Fédération Equestre Internationale (FEI) seated in Lausanne. The rider brought an action against the decision of the FEI in front of the Swiss courts, which accepted the objection of arbitration raised by the FEI. This led to an appeal by Nagel to the SFT challenging the validity of the arbitration clause. The court considered it "not admissible to hold that an arbitration agreement resulting from a global reference does not bind the person who, already knowing the existence of the arbitration clause when he signs the document referring to it and thereby satisfies the requirement of the written form, makes no objection to such a clause, and regards himself as bound by it" 35 . This behaviour "allows the author of the communication logically to deduce that the arbitration agreement corresponds to the actual wish of the person to whom it was addressed at the time when he accepted, in the specified form, the global reference" 36 . In this case, it was "established that the plaintiff already knew the arbitration clause inserted in the FEI regulations when he signed the model agreement, and he actually made use of it to have recourse to the CAS on the occasion of a previous dispute" 37 . Thus, "one is forced to conclude that the plaintiff agreed to submit to the arbitration agreement, validly giving his consent in formal terms by signing the model agreement, and confirming

31 For a comprehensive review of the jurisprudence of both the CAS and the SFT on the issue of consent to CAS jurisdiction, see Mavromati, D. (2015), "Arbitration clause in the contract or in the rules of the federation in disputes brought before the CAS", available at www.ssrn.com/abstract=2573612, accessed 1 February 2017.

32 For a first elaboration on this contractual structure, see Netzle, S. (1998), "Arbitration agreements by reference to regulations of sports organisations", Arbitration of Sports-Related Disputes ASA Special Series 11, 45-58. See more recently, Mavromati and Reeb, supra note 25, 35-37.

33 Nagel v. Fédération Equestre Internationale, supra note 28.

34 Roberts $v$. International basket Federation (FIBA) \& Court of Arbitration for Sport (CAS), SFT Case 4P.230/2000, Judgment of 7 February 2001. See also the original R. v. International Basketball Federation (FIBA), CAS award CAS 2000/A/262, preliminary award of 28 July 2000.

35 Nagel v. Fédération Equestre Internationale, supra note 28, para. 3.c.

36 Ibid.

37 Ibid. 
it by his unreserved acceptation of the arbitration clause contained expressis verbis in the documents sent to him when he entered for the competition in San Marino"38. The Court quickly brushed over the question of the free will of the athlete, it simply noted "[i]t does not emerge from the unappealable findings of the cantonal judges that the plaintiff would not have obtained his licence, and hence would not have been able to take part in the equestrian event such as the one in San Marino, if he had not accepted the arbitration agreement" 39 . This is definitely a rather formalistic way to deal with a thorny problem for CAS arbitration: athletes are in practice forced to accept the jurisdiction of the CAS or they will not get a license to compete. More importantly, the SFT added: "it is in all cases out of the question to treat as an excessive obligation, within the meaning of article 27 CC, adoption by reference of the arbitration clause contained in the defendant's regulations" ${ }^{40}$. In other words, the SFT held that even if the athlete's consent is forced, the validity of the clause would be upheld through a balance of interests. ${ }^{41}$

The permissive stance of the SFT with regard to the validity of CAS arbitration agreements was further reinforced by the Roberts decision in 2001. The decision involved a Basketball player challenging an arbitration clause in favour of the CAS included in the regulations of the International Basketball Federation (FIBA). The player was not a member of FIBA or of one of its affiliates. The SFT referred to the Swiss principle of trust (Vertrauensprinzip) to interpret whether the parties were bound by an arbitration clause by reference and concluded that an athlete is consenting to the general regulations of an SGB (and the CAS arbitration clause included therein) when he or she claims a license to participate in the competitions it organizes. ${ }^{42}$ Furthermore, the Court considered that "by his recourse to the Appeals Commission under those Internal Regulations, without entering any reservation regarding the arbitration clause of which he was aware, [Roberts] signified his consent to that clause" 43 . Moreover, "by lodging the

38 Ibid.

39 Ibid., para. 4. b).

40 Ibid.

41 In this context, the SFT evaluates whether the forced CAS arbitration is in the interest of the athlete. See Handschin, L. and Schütz, T.M. (2014), "Bemerkungen zum Fall Pechstein", Sport und Recht 21(5), 179-181.

42 Roberts $v$. International basket Federation (FIBA) \& Court of Arbitration for Sport (CAS), supra note 34, para. 2. a).

43 Ibid., translation from Reeb, M. (ed.). (2002), Digest of CAS Awards 1998-2000 (Vol. 2). The Hague: Kluwer Law International, 812. 
appeal he was implicitly applying for a general permit to play and the respondent was therefore also entitled to assume from this that he would recognize its rules, with which he was familiar" 44 . In other words, Roberts had to assume that FIBA was inviting him to take part in a process that would eventually lead him to abide by an arbitration clause in favour of CAS. Nagel and Roberts became a reference point in the jurisprudence of both the CAS ${ }^{45}$ and the SFT ${ }^{46}$. In both Roberts and Nagel, the SFT rightly insisted that the athletes did not object ex ante to the particular arbitration agreement, yet it fails to problematize the fact that if they had done so, they would not be allowed to compete. The imbalanced power constellation, as an SGB controls all the potential economic opportunities of an athlete or club in a particular sport, leaves no room for free choice from the side of the athlete or the club.

In its more recent jurisprudence, the SFT further entrenched its favourable assessment of arbitration by reference. In the Dodo case, a Brazilian football player was contesting the jurisdiction of the CAS to hear an appeal against an anti-doping decision adopted by a Brazilian anti-doping tribunal. The national federation did not include in its rules and regulations an arbitration clause referring this type of dispute to CAS. Nevertheless, the SFT held that the regulations of the Fédération Internationale

44 Ibid. The CAS had considered similarly that the "Appellant knew at the time he lodged the appeal and when he signed and accepted the Order of Procedure about the existence of the arbitration clause according to article 12.9 of the IR. Applying the principle of trust it was his obligation to decline the arbitration (and by that most probably also the right to appeal to the AC). Failing to do so, he had accepted the arbitration clause, which had been offered to him by Respondent." Roberts $v$. International basket Federation (FIBA) \& Court of Arbitration for Sport (CAS), supra note 34, para. 11.

45 For the Nagel case see Roberts $v$. International basket Federation (FIBA) \& Court of Arbitration for Sport (CAS), supra note 33, paras 39, 44. For the Roberts case see Union Cycliste Internationale (UCI) v. R. \& Fédération Française de Cyclisme (FFC), Arbitrage TAS Case 2002/A/431, award of 23 May 2003, para. 4.

46 See A. v. B., SFT Case 4P.253/2003, Judgment of 23 March 2004, para. 5.3; Cañas. v. ATP Tour, SFT Case 4P.172/2006, Judgment of 22 March 2007, para. 4.3.2.3; A. $v$. Fédération International de Football Association (FIFA) \& World Anti-Doping Agency (WADA), SFT Case 4A_460/2008, Judgment of 9 January 2009, para. 6.2; A. $v$. World Anti-Doping Agency (WADA), SFT Case 4A_358/2009, Judgment of 6 November 2009, para. 3.2.4; X. v. Y. \& Fédération Internationale de Football Association (FIFA), SFT Case 4A_548/2009, Judgement of 20 January 2010, paras 3.2.2 and 4.1; A. v. World Anti-Doping Agency (WADA), Fédération International de Football Association (FIFA) \& Cyprus Football Association (CFA), SFT Case 4A_640/2010, Judgment of 18 April 2011, para. 3.2.2. 
de Football Association (FIFA) providing for an appeal to CAS in doping cases are binding on the player. It observed that "[a]s a professional football player playing at the international level, he is a member of the Brazilian Football Association CBF, which for its part is a member of FIFA" 47 . Thus, "the FIFA Rules, particularly the jurisdiction of the CAS according to Art. 61 of the FIFA Statutes, apply also to the Appellant" 48 . This follows mainly from Article 1 (2) of the CBF Statutes, as it "provides, among other things, that a player belonging to the CBF must follow the FIFA Rules"49. It concluded by finding that " $[s]$ uch a general reference to the FIFA Rules and thus to the appeal rights of FIFA and WADA contained in the FIFA Statutes is sufficient to establish the jurisdiction of the CAS pursuant to R47 of the CAS-Code" 50 . In other words, a player forced to submit to the statutes of the Brazilian federation to exercise his profession, is bound to the jurisdiction of the CAS enshrined in the Statutes of a Swiss association of which he is not even a member. Distinguishing a consensual basis in this factual constellation is undoubtedly a masterpiece of legal fiction by the SFT. The validity of this type of consent to CAS arbitration, via a global reference made by the statutes of a national federation to the FIFA statutes, was later confirmed by the SFT ${ }^{51}$ and the $\mathrm{CAS}^{52}$.

The willingness of the SFT to recognize the validity of the consent to CAS arbitration is not solely embodied in its jurisprudence on arbitration clauses by reference, it is also vividly visible in other decisions. An example is a decision regarding the competence of the CAS to deal with a dispute resulting from a request made to the FIFA by a club and a player for an International Transfer Certificate (ITC). ${ }^{53}$ Obtaining an ITC is a requirement for fielding a player coming from a different Football Association than the one the new club is affiliated to. In that case, the former association of the player refused to deliver the ITC due to an outstanding contractual dispute between the player and its former club. This dispute was

47 A. v. Fédération International de Football Association (FIFA) \& World Anti-Doping Agency (WADA), supra note 46, para. 6.2.

49 Ibid.

50 Ibid.

51 A. v. World Anti-Doping Agency (WADA), Fédération International de Football Association (FIFA) \& Cyprus Football Association (CFA), supra note 46, para. 3.2.2.

52 Fédération Internationale de Football Association (FIFA) v. Malta Football Association (MFA) \& $M$ and CAS 2008/A/1627 World Anti Doping Agency (WADA) v. MFA \& M., CAS Case 2008/A/1575, award of 9 February 2009, paras 1-7.

53 X. v. Y. \& Fédération Internationale de Football Association (FIFA), supra note 46, partial award on lis pendens and jurisdiction of 7 October 2009. 
referred to the FIFA Dispute Resolution Chamber (DRC) and the player contested the jurisdiction of CAS to review the decision of the DRC. The SFT considered that the player could not invoke a lack of knowledge of the FIFA Regulations on the Status and Transfer of Players (RSTP), which foresees that the DRC's decisions are exclusively appealable to the CAS. ${ }^{54}$ Instead, by requesting an ITC, the player "admitted the application of the specific regulation adopted by the Respondent federation and he submitted to the procedure foreseen by the regulations to decide the disputes in connection with the filing of a request for an ITC" 55 . Thus, the SFT held that "[i]t must be acknowledged with the CAS that the Appellant could not without violating the rules of good faith submit a request for an ITC to FIFA (or at least participate in such a request in his favour) and invoke the specific provision of the RSTP whilst refusing to participate in the procedure instituted by the same provision to resolve the disputes in connection with such a request, in other words by compelling the other party, allegedly victim of a breach of contract he committed, to sue him in front of an ordinary court to dispose of a dispute which was not within the exclusive jurisdiction of the ordinary courts" 56 . Moreover, the player "subsequently let himself be drawn in front of the DRC without the least objection" 57 . Hence, he "conclusively showed by his behavior that he submitted to the regulations adopted by [FIFA] to decide disputes such as the one at hand" 58 . As in the Nagel and Roberts case, the SFT seems to reproach the player's lack of early objection to CAS arbitration and locates his consent in his appearance in front of the FIFA DRC. This is notwithstanding the fact that, if the player was to be able to play quickly for a new club, i.e. exercise his right to work, the club was in practice forced to obtain an ITC from FIFA.

Nonetheless, there is a limit to the liberalism of the SFT. The jurisdiction of the CAS is only recognized if there is a written reference to the statute or the rules and regulations of a SGB where one can find a CAS arbitration agreement. Thus, for example, the SFT has supported a CAS panel denying its jurisdiction in a case involving the FIFA RSTP, because at that point in time FIFA had not introduced any arbitration clause in favour of the CAS. ${ }^{59}$ Similarly, if a national federation did not include a

54 Ibid., para. 4.2.2.

55 Ibid.

56 Ibid.

57 Ibid.

58 Ibid.

59 Ibid. 
clear arbitration clause in its statutes or regulations, the global reference to the FIFA rules is insufficient, as they do not provide for a CAS arbitration clause covering all types of football disputes. The SFT ${ }^{60}$ and the CAS ${ }^{61}$ have repeatedly found that the CAS has no jurisdiction to deal with this kind of dispute. Alternatively, the arbitration clause might refer to a precise characteristic of the dispute as its "international dimension". If this characteristic is absent then no recourse to CAS arbitration can be made. ${ }^{62}$ Finally, the SFT held that a general jurisdiction of CAS could not derive, as the CAS panel had thought, ${ }^{63}$ from an arbitration clause included in the entry form to a specific international competition, as the dispute en cause was not directly connected to that competition. ${ }^{64}$ These cases point at the need for the existence of a rule referring a specific dispute to the jurisdiction of the CAS, they embody the well-known principles of legality and publicity. However, they do not imply free consent as a prerequisite.

As pointed out by a seasoned observer of the CAS and the SFT, an "appeal on the grounds that the athlete had no alternative but to submit to the arbitration agreement in favour of the CAS and that therefore there was a lack of free will on the part of the athlete when he entered into the corresponding agreement making the arbitration agreement void will [...] probably have little prospect of succeeding" ${ }^{65}$. The SFT is careful not to take into account whether the athletes have any free choice in subjecting themselves to the SGBs' regulations and the CAS arbitration clauses they include. Yet, if athletes wish to take part in the Olympics, the world speedskating championships, or just the Brazilian football league they must accept the rules imposed by the SGBs. In any event, there is very little value, in the course of a short professional career, in starting multi-year litigation to obtain in front of a national court the right to compete in sport-

$60 X v$. Y, SFT Case 4A_160/2007, Judgment of 28 August 2007.

61 The CAS has had to deal with this particular question in numerous instances. For a good summary of its view on the matter, see Al-Wehda Club $v$. Saudi Arabian Football Federation (SAFF), CAS Case 2011/A/2472, award of 12 August 2011, para. 20.

62 A. v. Trabzonspor Kulübü Dernegi \& Turkish Football Federation (TFF), supra note 26, confirming Omer Riza v. Trabzonspor Kulübü Dernegi \& Turkish Football Federation, CAS case 2010/A/1996, award of 10 June 2010.

63 World Anti-doping Agency (WADA) v. International Ice Hockey Federation (IIHF) \& Florian Busch, CAS case 2008/A/1564, award of 23 June 2009, paras 1-26.

64 A. v. World Anti-Doping Agency (WADA), supra note 46, paras 3.2.3 and 3.2.4.

65 Netzle, S. (2011), "Appeals against Arbitral Awards by the CAS”, Bulletin TAS/CAS (2), 19-26, 23. 
ing competitions. ${ }^{66}$ Hence, in practice, there is not much an athlete can do, but to defend his case in front of the federations' disciplinary bodies and by doing so he will most likely be deemed as having accepted a CAS arbitration clause. This état de fait has been recognized in the literature, and acknowledged by the SFT itself, before the German courts decided to tackle it in the Pechstein case.

B. The Pechstein case: Endpoint for the consensual myth?

The weakness of the consensual myth as support for the validity of CAS arbitration agreements imposed on athletes and clubs by the SGBs has long been acknowledged. ${ }^{67}$ However, it is only with the two Pechstein rulings of the LG and OLG München that it has finally been openly confronted.

66 A point well illustrated by the judicial "ordeal" suffered by German athlete Katrin Krabbe in the 1990s, recalled in Faylor, J.A. (2001), "The Dismantling of a German Champion: Katrin Krabbe and her Ordeal with the German Track and Field Association and the International Amateur Athletic Federation (IAAF)", Arbitration International 17(2), 163-172.

67 See Netzle, supra note 32, 53. 


\section{The mounting realist critique: This is not a consensual arbitration}

\section{a. The realism of the doctrine}

The problematic role of free consent as a foundation to arbitration is not exclusive to sports arbitration. ${ }^{68}$ It has been abundantly debated in the framework of consumer and employment arbitration in the US. ${ }^{69}$ However, the key difference is that both consumers and employees have a (limited) choice regarding their contractual partners and the conditions offered. This choice is relative as few are capable of deciphering the legal fine print of a consumer contract or in a position to refuse a specific job, but it is potentially there. In sports the situation is structurally different: there is not even a potential choice. The monopoly of the SGBs over their competitions is such that an international-level athlete wanting to compete is left with no real alternative: accept a CAS arbitration clause or play alone in your garden. ${ }^{70}$ The consensual myth has been convincingly exposed as a "dogma" ${ }^{\text {" by numerous authors. }}{ }^{72}$ Some refer in euphemistic terms to

68 Forced arbitration in the US recently came under intense scrutiny by the New York Times. See Silver-Greenberg, J. and Gebeloff, R. (2015), "Arbitration Everywhere, Stacking the Deck of Justice", New York Times, 31 October, available at http://www. nytimes.com/2015/11/01/business/dealbook/arbitration-everywhere-stacking-the-d eck-of-justice.html, accessed 1 February 2017; Silver-Greenberg, J. and Gebeloff, R. (2015), "In Arbitration, a Privatization of the Justice System", New York Times, 1 November, available at http://www.nytimes.com/2015/11/02/business/dealbook/in -arbitration-a-privatization-of-the-justice-system.html, accessed 1 February 2017.

69 See, for example, Demaine, L.J. and Hensler, D.R. (2004), “Volunteering' to Arbitrate Through Predispute Arbitration Clauses: The Average Consumer's Experience", Law and Contemporary Problems 67(1-2), 55-74; Roma, E. (2011), "Mandatory Arbitration Clauses in Employment Contracts and the Need for Meaningful Judicial Review", Journal of Gender, Social Policy \& Law 12(3), 519-544; Moses, M.L. (2014), "Challenges for the Future: the Diminishing Role of Consent in Arbitration", Transnational Dispute Management 11(4), 1-10.

70 This is a famous alternative referred to by the SFT in its Cañas case. See Cañas. $v$. ATP Tour, supra note 46, para. 4.3.2.2.

71 "L'auteur prend notamment le pari de se départir du dogme du caractère consensuel de l'arbitrage pour affirmer sans détours que l'arbitrage sportif n'est pas consensuel." The words are from Gabrielle Kaufmann-Kohler in her preface to Rigozzi, A. (2005), L'arbitrage international en matière de sport. Basel: Helbing \& Lichtenhahn, XV.

72 See Ibid., 421-433; Rigozzi, A. and Robert-Tissot, F. (2015), "Consent in Sports Arbitration: Its Multiple Aspects" In: E. Geisinger and E. Trabaldo de Mestral (eds), Sports Arbitration: A Coach for other players?. New York: Jurisnet LLC, 59-94; Maisonneuve, supra note 7, 191-225; Steingruber, supra note 13; Pinna, supra note 
"inherent particularities" 73 , and acknowledge "that the formal requirements of Article 178 PILA as well as the consent to arbitrate are not always clearly established" 74 . In short, "sports arbitration is far from the traditional idea of arbitration being the consensual alternative dispute adjudication process that we read about in every textbook on arbitration"75. Rather, "it is clear that sports arbitration is fundamentally non-consensual in nature, since athletes have no other choice but to agree to whatever is contained in the statutes or regulations of their sports governing bodies" 76 . Admittedly, "[f]rom the point of view of the athlete concerned, it makes little difference whether he is bound to the jurisdiction of the arbitral tribunal by virtue of a statutory regulation or by virtue of a unilateral regulation imposed by a monopoly federation"77. In functional terms, CAS arbitration is analogous to mandatory arbitration imposed by the state.

\section{b. The confession of the SFT in the Cañas case}

In 2007, in its decision in the now famous Cañas case, the SFT carefully acknowledged this critique. The court was facing a question relating to the validity of a waiver of appeal of a CAS award signed by a professional ten-

17; Yamdjie, E. (2013), Le consentement dans l'arbitrage des litiges sportifs. Université Nice Sophia Antipolis, available at https://tel.archives-ouvertes.fr/tel-01215802/do cument, accessed 1 February 2017.

73 Mavromati, D. (2011), "Selected issues related to CAS jurisdiction in the light of the jurisprudence of the Swiss Supreme Court", CAS Bulletin/Bulletin TAS (1), 3140, available at https://www.tas-cas.org/fileadmin/user_upload/Bulletin_1_2011.p df, accessed 1 February 2017.

74 Ibid.

75 Rigozzi and Robert-Tissot, supra note 72, 59.

76 Ibid., 60. Similarly, Steingruber, A.M. (2009), "Sports Arbitration: how the structure and other features of competitive sports affect consent as it relates to waiving judicial control", American Review of International Arbitration 20(1), 59-96, 73; Weston, M.A. (2009), "Doping Control, Mandatory Arbitration, and Process Dangers for Accused Athletes in International Sports", Pepperdine Dispute Resolution Law Journal 10(1), 5-50, 8; Yi, D.H. (2006), "Turning Medals into Metal: Evaluating the Court of Arbitration of Sport as an International Tribunal", Asper Review of International Business and Trade Law 6, 289-341, 312.

77 Haas, U. (2012), "Role and application of article 6 of the European Convention on Human Rights in CAS procedures", International Sports Law Review 12(3), 4360,45 . 
nis player. ${ }^{78}$ It found that sporting competitions were characterized by a structural imbalance of power between athletes and SGBs due to the hierarchical structure of sports organizations and held that "[i]t is clear that an athlete's waiver of appeal against future awards will not generally be the result of a freely expressed desire on their part"79. In an interesting display of both honesty and self-critical reflexivity, the SFT recognized that its socalled liberal position regarding the validity of the consent to the arbitration clause could be perceived as "illogical" 80 in light of its reasoning in Cañas. Nonetheless, the Court justified this differentiated treatment of the consensual nature of the waiver of appeal and the CAS arbitration clause as a function of the need for a quick and knowledgeable resolution of sporting disputes. ${ }^{81}$ In this context, it deemed that "maintaining the right to challenge an award is the proper counterbalance to the liberal approach underlying the examination of arbitration agreements in sports-related disputes" 82 . Since then the SFT continues to reaffirm its "benevolence" 83 ,

78 On this aspect of the case, see Krausz, N. (2011), "Waiver of Appeal to the Swiss Federal Tribunal: Recent Evolution of the Case Law and Compatibility with ECHR, Article 6", Journal of International Arbitration 28(2), 137-162, 144-146.

79 Cañas. v. ATP Tour, supra note 46, para. 4.3.2.2. The English translation used is available at http://law.marquette.edu/assets/sports-law/pdf/2012-conf-canas-english .pdf, accessed 1 February 2017).

80 "Qu'il y ait un certain illogisme, en théorie, à traiter de manière différente la convention d'arbitrage et la renonciation conventionnelle au recours, sous les rapports de la forme et du consentement, est sans doute vrai", Ibid., 4.3.2.3. Festering on this acknowledgement, see Monheim, D. (2008), "Die Freiwilligkeit von Schiedsabreden im Sport und das Rechtsstaatsprinzip", Sport und Recht 15(1), 811.

81 "Toutefois, en dépit des apparences, ce traitement différencié obéit à une logique qui consiste, d'une part, à favoriser la liquidation rapide des litiges, notamment en matière de sport, par des tribunaux arbitraux spécialisés présentant des garanties suffisantes d'indépendance et d'impartialité [...], tout en veillant, d'autre part, à ce que les parties, et singulièrement les sportifs professionnels, ne renoncent pas à la légère à leur droit d'attaquer les sentences de la dernière instance arbitrale devant l'autorité judiciaire suprême de l'Etat du siège du tribunal arbitral., Cañas. v. ATP Tour, supra note 46, para. 4.3.2.3.

82 Ibid.

83 X. v. Y. \& Fédération Internationale de Football Association (FIFA), supra note 46, para. 4.1; Fédération International de Football Association (FIFA) \& Cyprus Football Association (CFA), supra note 46, para. 3.2.2; X. v. Y. sarl, SFT Case 4A_246/2011, Judgment of 7 November 2011, para. 2.2.2; A \& B v. World Anti- Doping Agency (WADA) \& Flemish Tennis Federation, SFT Case 4A_428/2011, Judgment of 13 February 2012, para. 3.2.3. 
"generosity" 84 and "liberalism" 85 in assessing the validity of a CAS arbitration clause. From the fact that a "CAS arbitration clause is typical of the sport requirements", it derived that "there is practically no elite sport without consent to sport arbitration" 86 . This is the closest the SFT gets to openly conceding that forced consent is, simply put, needed and that the free will of the athletes must be disregarded in the process.

As the realist critique started to bite, the SFT was forced to justify its position regarding the validity of CAS arbitration agreements. While the Pechstein rulings of the LG and OLG München clearly affirmed and problematized the forced nature of the consent to CAS arbitration agreements, the BGH decided to fall back to the SFT's contradictory position.

\section{The Pechstein rulings: Consent, or no consent? That is the question}

a. The ruling of the LG München: Not in Claudia Pechstein's name!

The question of the existence of a valid arbitration agreement between Claudia Pechstein and the International Skating Union (ISU) was decisive to affirm the competence of the LG München to hear the dispute. If recognized as valid, the agreement could preclude the jurisdiction of the German courts. Thus, the LG decided first to analyze the validity of the arbitration clause under Swiss law, while the applicable law was based on German private international law rules. ${ }^{87}$ It found that the ISU was a monopolist and deprived Pechstein of any free choice. In other words, if she had opposed the signing of the clause, she would not have been able to compete in the 2009 World Championships. ${ }^{88}$ Taking part in the competition

84 A. v. World Anti-Doping Agency (WADA), supra note 46, para. 3.2.4; Fédération International de Football Association (FIFA) \& Cyprus Football Association (CFA), supra note 46, para. 3.2.2; X. v. Y. sarl, supra note 83, para. 2.2.2; X. v. Y. \& Fédération Internationale de Football Association (FIFA), supra note 46, para. 3.2.3.

$85 X . v$. Y. \& Fédération Internationale de Football Association (FIFA) supra note 46, para. 4.1; A \& B v. World Anti-Doping Agency (WADA) \& Flemish Tennis Federation, supra note 83 , para. 3.2.3.

86 Ibid., para. 3.2.3.

87 LG München I, SchiedsVZ 2014, 100- 112, $104 f$.

88 "Ohne Unterzeichnung der Schiedsvereinbarung der Beklagten zu 2) wäre es der Klägerin nicht möglich gewesen, an dem Wettkampf am 7./8.2.2009 in Hamar teilzunehmen." Ibid., 105. 
of the ISU is the "sole possibility" 89 for Pechstein to exercise her profession. Due to the "structural imbalance" (strukturelles Ungleichgewicht) between the ISU and Pechstein, she is practically deprived of the ability to choose to submit to arbitration. This is not contradicted by the fact that Pechstein did not positively object to the arbitral clause. ${ }^{90}$

In the eyes of the tribunal, the lack of free consent is sufficient to invalidate the arbitration clause. ${ }^{91}$ The LG reaches this conclusion, not un-controversially ${ }^{92}$, on the basis of Article 27 paragraph 2 of the Swiss Civil Code. To this end, it openly disregards the "benevolent" (wohlwollende) interpretation of the SFT regarding the validity of CAS arbitration agreements. ${ }^{93}$ The LG is of the opinion that this "benevolent" interpretation is contrary to Article 6 (1) European Convention of Human Rights (ECHR). ${ }^{94}$ In fact, the difficulty posed by the reconciliation of forced consent to CAS arbitration with the Article 6 (1) ECHR has been previously highlighted in the literature. ${ }^{95} \mathrm{I}$ do not want to enter further into this debate, suffice to mention that many scholars believe that the forced

89 "Die Wettkampfteilnahme bei den Beklagten ist für die Klägerin angesichts deren Monopolstellung die einzige Möglichkeit, ihren Beruf angemessen auszuüben und gegen andere professionelle Konkurrenten anzutreten." Ibid.

90 "Entgegen der Auffassung der Beklagten zu 1) ist eine Freiwilligkeit nicht aufgrund des fehlenden Vorbringens von Einwänden oder der Abänderung oder Streichung der Zuständigkeit des Schiedsgerichtes anzunehmen.” Ibid.

91 Ibid.

92 The LG München was widely criticized on that point in German scholarship, a criticism that might have led the OLG München to favour a competition law analysis. See, for example: Haas, U. (2014), "Zwangsschiedsgerichtsbarkeit im Sport und EMRK", ASA Bulletin 32(4), 707-734; Schulze, G. (2014), "Fortentwicklung des Schweizer Vertragsrechts und Präklusion bei der inzidenten Anerkennung eines CAS-Entscheids", Sport und Recht 21(4), 139-143, 140-141; Pfeiffer, T. (2014), "Rechtsgeschäftliche Entscheidungsfreiheit beim Abschluss von Schiedsvereinbarungen: Bemerkungen zum Pechstein-Urteil des Landgerichts München I vom 26 Februar 2014", Zeitschrift für Schiedsverfahren 12(3), 161-165, 163.

93 See references to the Cañas decision of the SFT at LG München I, supra note 87, $106 f$.

94 "Dieser Argumentation kann angesichts der Garantien der Art. 6 und 13 der Europäischen Menschenrechtskonvention (im Folgenden: EMRK) nicht gefolgt werden." Ibid., 107.

95 Critical of the compatibility, see Lukomski, J. (2013), "Arbitration clauses in sport governing bodies' statutes: consent or constraint? Analysis from the perspective of Article 6(1) of the European Convention on Human Rights", International Sports Law Journal 13(1), 60-70, 70. Pointing at the difficulty, Besson, S. (2006), "Arbitration and Human Rights", ASA Bulletin 24(3), 395-416, 398; Steingruber, supra note 76, 74. See also, recently, Frumer, P. (2016), "Larbitrage sportif, la lute contre 
nature of CAS arbitration is not per se contradictory to Article 6 (1) ECHR. ${ }^{96}$ In any event, the LG's decision shone a spotlight on the post-consensual nature of CAS arbitration, a view shared, though very differently, by the OLG München.

b. The ruling of the OLG München: Forced CAS arbitration as an abuse of ISU's monopoly

On appeal, the OLG faced the same legal question as the LG: does a valid arbitration clause between Claudia Pechstein and the ISU preclude its competence to hear the matter? It also answered this question negatively, but relied on very different reasoning, anchored in German competition law instead of the more classical private international law analysis conducted by the LG. ${ }^{97}$ In fact, it expressly rejected the legal reasoning of the LG in its decision, and insisted that free consent is not a necessary condition for the validity of an arbitration clause under Article 6 (1) ECHR. ${ }^{98}$ The thrust of the court's argument to find in favour of Claudia Pechstein lies in the finding that the ISU abused its monopoly position on the market for the organization of World Championships in speed skating by forcing her to agree to a CAS arbitration clause. ${ }^{99}$ Indeed, the OLG concludes

le dopage et le respect des droits fondamentaux des sportifs professionnels : une incertitude peu glorieuse", Revue Trimestrielle de Droit Européen 27(108), 817-854. Asking a similar question in the US context, Gubi, J. (2008), "The Olympic Binding Arbitration Clause and the Court of Arbitration for Sport: An Analysis of Due Process Concerns", Fordham Intellectual Property Media \& Entertainment Law Journal 18(4), 997-1024, 1011.

96 See Haas, supra note 92, 80; Haas, supra note 77, 51-52; Rigozzi and Robert-Tissot, supra note 72, 72; Muresan, R. and Korff, N. (2014), "Sportschiedsgerichtsbarkeit: Wie weiter nach dem "Pechstein-Urteil” des Landgerichts München?”, Causa Sport 10(3), 199-211, 209-210.

97 On this argumentative shift, see Rombach, A. (2015), "The "Pechstein-judgment" of the OLG München: What does it mean for international sports and commercial arbitration?", Zeitschrift für Schiedsverfahren 13(3), 105-111.

98 "Entgegen der Auffassung des Landgerichts sind Schiedsvereinbarungen zwischen einem marktbeherrschenden Veranstalter internationaler Sportwettkämpfe und den daran teilnehmenden Athleten nicht schon deshalb generell unwirksam, weil es an einer freien Willensbildung der Athleten bei der Unterzeichnung fehlte." OLG München, SchiedsVZ 2015, 40-47, 43.

$99 \mathrm{Ibid}$. On the competition law dimension of the case, see: Duval, A. and Van Rompuy, B. (2016), "Protecting Athletes' Right to a Fair Trial Through EU Competition Law: The Pechstein Case" In: C. Paulussen et al. (eds), Fundamental Rights 
that a forced arbitration clause in favour of the CAS constitutes an unfair trading condition that would not have been agreed if ISU were not in a dominant position on the market for international skating competitions. The unfair nature of this clause derives from the OLG's finding of a lack independence of the CAS from the SGBs. ${ }^{100}$ The forced nature of CAS arbitration as identified by the LG is thus re-casted in competition law terms. ${ }^{101}$ Nonetheless, the underlying factual assessment remains identical: athletes (and clubs, officials, national federations etc) are forced by a global monopolist (ISU or any other SGB) to adhere to a CAS arbitration agreement if they want to participate in international competitions and exercise their profession. In other words, there is no alternative! The OLG, however, is not as radical as the LG and some authors ${ }^{102}$, as it recognizes that a forced arbitration clause is not per se an abuse of a dominant position, nor necessarily contrary to Article 6 (1) ECHR. ${ }^{103}$

\section{c. The ruling of the BGH: Saving the consensual foundations of the CAS}

Finally, after two years of uncertainty with regard to the future of the CAS, on 7 June 2016 came the much-expected Pechstein ruling of the highest German civil court, the BGH. The court strongly sided with the CAS, by rejecting the reasoning of both the LG and the OLG. I have criticized the court elsewhere for its poor understanding of the institutional functioning of the CAS, and for not having considered the OLG's - in my view - legiti-

in International and European Law. The Hague: Springer, 245-276; Stancke, F. (2015), "Pechstein und der aktuelle Stand des Sportkartellrechts", Sport und Recht 22(2), 46-51.

100 For more details on this assessment, see Duval and Van Rompuy, supra note 99, 266-275.

101 A possibility envisaged (and discarded) early on by Netzle, supra note 32, 53-54.

102 See: Monheim (2008), supra note 80, 8-11; Monheim, D. (2014), "Das Ende des Schiedszwangs im Sport - Der Fall Pechstein", Sport und Recht 3, 90-94; Heermann, P.W. (2014), "Freiwilligkeit von Schiedsvereinbarungen in der Sportgerichtsbarkeit", Zeitschrift für Schiedsverfahren 12(2), 66-79.

103 On this rather favourable assessment of the validity of CAS arbitration by the OLG, see: Brandner, G. and Kläger, R. (2015), "Ein Sieg über (oder für) das System der Sportschiedsgerichtsbarkeit", Zeitschrift für Schiedsverfahren 13(3), 112119; Scherrer, U. et al. (2015), "Pechstein ist kein "Bosman" der Sportschiedsgerichtsbarkeit”, Zeitschrift für Schiedsverfabren 13(3), 161. 
mate concerns with regard to its lack of independence. ${ }^{104}$ Here, I will briefly analyze the BGH's holdings involving the consensual foundation of CAS arbitration in the Pechstein factual constellation.

The BGH in its judgment assessed whether the CAS arbitration clause was compatible with German competition law, in particular $\mathbb{1 9}$ GWB. ${ }^{105}$ Its main conclusion was that the "demand for an arbitration agreement which provides for the CAS as the arbitral tribunal, in any event, is justified by objective reasons and does not contradict the general statutory determinations" ${ }^{106}$. To reach such a conclusion, the court considered, and this is the most explicit and controversial argument regarding the free consent of Claudia Pechstein to CAS arbitration, that she "voluntarily and, thus, validly submitted herself to the arbitration agreement" ${ }^{107}$. In particular, the court added, it "has not been determined or argued that the Claimant was caused to do so by an illegal threat or deception, let alone by physical force" 108 , thus, denying the fact that economic blackmail might have the same effect as sheer force or threats (which could be of an economic nature). Yet, the court, probably conscious of the "surrealism"109 of this statement, qualified it in the following paragraph. The judges recognized that "if one of the contracting partners has such excessive power that he can de facto dictate contractual terms, this results in third party deter-

104 For the core elements of my critique of the judgment, see: Duval, A. (2016), "The Pechstein case: Transnational constitutionalism in inaction at the Bundesgerichtshof", Verfassungsblog, 10 June, available at http://verfassungsblog.de/the-pechstei n-case-transnational-constitutionalism-in-inaction-at-the-bundesgerichtshof/, accessed 1 February 2017. A critical view widely shared by: Heermann, P.W. (2016), "Die Sportschiedsgerichtsbarkeit nach dem Pechstein-Urteil des BGH", Neue Juristische Wochenschrift 69(31), 2224-2227; Thorn, K. and Lasthaus, C. (2016), "Das Pechstein-Urteil des BGH - Ein Freibrief für die Sportsschiedsgerichtsbarkeit", IPRax-Praxis des Internationalen Privat- und Verfabrensrechts 36(5), 426-431; Rombach, A. (2016), "Pechstein vs. CAS: Game, Set and Match for Sports Arbitration?”, SchiedsVZ, 276-279.

$105 \mathrm{BGH}$, supra note 2, paras 42ff. The English translation of the BGH's ruling used is the one by Rombach, supra note 104, 268.

106 BGH, supra note 2, para. 48.

107 Ibid., para. 53.

108 Ibid. A view strongly supported by Haas, U. (2016), “The German Federal Court on Treacherous Ice - A Final Point in the Pechstein Case” In: C. Müller et al. (eds), New Developments in International Commercial Arbitration. Geneva/Zurich: Schulthess, 219-265, 258.

109 See Duval, A. (2016), "The BGH's Pechstein Decision: A Surrealist Ruling”, ASSER International Sports Law Blog, 8 June, available at http://www.asser.nl/Spo rtsLaw/Blog/post/the-bgh-s-pechstein-decision-a-surrealist-ruling, accessed 1 February 2017. 
mination of the intent (Fremdbestimmung) for the other contracting partner" 110 , and conceded that Pechstein "was determined by a third party"111. The clear contradictory nature of this finding with the previously claimed free consent of Pechstein to the clause, highlights the perilous and acrobatic nature of the BGH's legal reasoning. This acknowledgment leads the $\mathrm{BGH}$ to conduct a balancing exercise between Pechstein's rights and the interests of ISU in having a CAS arbitration clause, which in the end favours the latter. ${ }^{112}$ Furthermore, the BGH claimed that the ECtHR would adopt a similar conclusion, for "the fact that the Claimant [Claudia Pechstein] was required to sign the registration for competition demanded by the Respondent 2 [ISU] in order to exercise her profession does not lead to an involuntary arbitration agreement which violates the convention"113. Finally, and rather unsurprisingly in light of the BGH's previous findings, it disavowed the LG's interpretation of Swiss law and recognized that it follows from the SFT's case law that "a professional athlete will sign the arbitration agreement only due to the fact that he is required to do so in order to exercise his profession, but that the arbitration agreement is nonetheless valid"114. It even mentioned the "theoretical contradiction in the treatment of the arbitration agreement and the waiver of legal remedies" 115 .

The BGH's ruling, like the SFT's jurisprudence, on the consent to CAS arbitration is a perfect illustration of legal doublespeak. Doublespeak is a language that deliberately reverses the meaning of words, inspired by George Orwell's famous novel 1984. With regard to the consensual foundation of CAS arbitration, both the SFT and the BGH seem to be conscious of their slide towards doublespeak. I believe they fail to resist it because they are convinced of the necessity of preserving the CAS without fully embracing the alternative foundations that could be available to secure and legitimize its jurisdiction. Yet if the CAS is not truly speaking in the name of Claudia Pechstein, in whose name is it speaking then?

110 BGH, supra note 2, para. 55.

111 Ibid.

112 Ibid., para. 62.

113 Ibid., para. 65.

114 Ibid., para. 70.

115 Ibid. 


\section{Speaking in the name of $(. .$.$) ?$}

The CAS faces a similar "foundational uncertainty"116 as that bearing on other international courts. If the voluntary and consensual origin of the arbitrators' mission is an essential, quasi- ontological feature of arbitration $^{117}$, then it is difficult to accept that CAS arbitration agreements are valid. ${ }^{118}$ CAS arbitration would go beyond the conceptual boundaries of the notion of arbitration. ${ }^{119}$ The legitimacy of the CAS cannot be rooted in private autonomy; it must derive from somewhere else. The question is then, whether the CAS can be speaking in other names, no less legitimate than Claudia Pechstein's? The OLG München found that "important practical reasons" (gewichtige sachgerechte Gründe) ${ }^{120}$ speak in favour of the necessity of forced CAS arbitration. ${ }^{121}$ Four ideal-typical names, illustrating the "multifunctionality" 122 of the CAS, can be discerned in the literature to ground the legitimacy and the validity of CAS arbitration: state delegation, efficiency, proximity and equality.

116 Von Bogdandy, A. and Venzke, I. (2013), "On the Functions of International Courts: An Appraisal in Light of Their Burgeoning Public Authority", Leiden Journal of International Law 26(1), 49-72, 53.

117 "Quant à l'origine volontaire de la mission de l'arbitre, elle est, elle aussi, essentielle. Les arbitrages forcés ne sont donc pas de véritables arbitrages, mais une variété de juridictions d'exception, dont le pouvoir de juger procède, pour certains litiges spécifiques, d'une délégation de l'Etat, et auxquelles le législateur a souhaité appliquer tout ou partie du régime de l'arbitrage." Jarrosson, supra note $16,19$.

118 In other words: "[d]as ist aber doch denklogisch ausgeschlossen - ohne wirksame Schiedsabrede kann es keinen wirksamen Schiedspruch geben!” Monheim (2014), supra note 102, 93.

119 As: "s'affranchir de la volonté des parties pour le recours à l'arbitrage exclut la qualification d'arbitrage.” Jarrosson, supra note 16, 20.

120 OLG München, supra note 98, 43.

121 Some commentators doubt that alternative names can be summoned to substitute the lack of free consent. Because, "so überzeugend diese Gründe auch sein mögen, so wenig sind sie doch isoliert betrachtet geeignet, das Erfordernis der Freiwilligkeit einer Unterwerfung unter die Sportschiedsgerichtsbarkeit in Frage zu stellen". Heermann, supra note 102, 75.

122 On multifunctionality, see Von Bogdandy and Venzke (2014), supra note 1, 5-17. 


\section{A. In the name of... the States}

In some, especially American ${ }^{123}$, contributions, reference is made to the adoption of the World Anti-Doping Code (WADC) ${ }^{124}$ and the International Convention against Doping in Sport ${ }^{125}$ to legally construct the jurisdiction of the CAS as a state delegation. The CAS jurisdiction would be based on the state consent doctrine traditionally used in the framework of public international law. However, there is no such clearly worded delegation included in the Convention ${ }^{126}$, nor are the States party to the WADC, which includes a provision imposing CAS arbitration for international cases. ${ }^{127}$ In fact, some States (France for example) specifically object to exclusive CAS jurisdiction in anti-doping disputes. ${ }^{128}$ Neither is the World Anti-Doping Agency an international organization grounded in an international treaty. If there is a delegation it is very much implicit, through a soft endorsement, but it can hardly be the main source of an alternative legitimacy for forced CAS arbitration. ${ }^{129}$ This soft endorsement, or "low visibility delegation" 130 , could be used as an additional argument to support the validity of a forced jurisdiction of the CAS, ${ }^{131}$ but it does not con-

123 See Ravjani, A. (2009), "The Court of Arbitration for Sport: A subtle form of international delegation", Journal of International Media and Entertainment Law 2(2), 241-284.

124 The latest 2015 version of the WADC is available at https://www.wada-ama.org/e n/resources/the-code/world-anti-doping-code, accessed 1 February 2017.

125 The Convention was adopted in October 2005 and entered into force in February 2007. The full text of the convention is available at http://portal.unesco.org/e n/ev.php-URL_ID=31037\&URL_DO=DO_TOPIC\&URL_SECTION=201.html, accessed 1 February 2017.

126 The CAS is not mentioned in the convention.

127 Though, Article 22.4 of the WADC symbolically indicates that "[e]ach government will respect arbitration as the preferred means of resolving doping-related disputes, subject to human and fundamental rights and applicable national law."

128 For example, Article L232-24 of the French Code du Sport foresees that appeals against decisions of the French Anti-Doping Agency (Agence française de lutte contre le dopage) can be lodged only with the administrative courts.

129 A point rightly highlighted by the OLG München in its Pechstein judgment. See OLG München, supra note 98, 43.

130 Ravjani, supra note 123, 260.

131 In 2003, the SFT referred to the Copenhagen Declaration on anti-doping that predated the UNESCO Convention to support its recognition of the CAS as an independent tribunal. It held: "Il faut y voir un signe tangible de la confiance que les Etats et tous les milieux concernés par la lutte contre le dopage accordent au TAS. On imagine mal que les intéressés aient pu consacrer de manière aussi éclatante le pouvoir juridictionnel de cette institution d'arbitrage, s'ils avaient eu 
stitute a formal state delegation, nor can it stand as an isolated foundation to legitimize the binding jurisdiction of the CAS.

\section{B. In the name of...efficiency}

Another foundation often referred to in the literature is the so-called "utilitarian"132 justification. The CAS is perceived, in cost-benefit terms, as the most efficient institution to solve sporting disputes. ${ }^{133}$ It is touted as a faster and cheaper decision-making mechanism than national courts. This line of argument is supported by references to the painful experiences of athletes having tried to use national courts in sporting disputes. ${ }^{134}$ Moreover, the need for a quick resolution is considered paramount in the sporting context, in order to ensure the smooth running of an on-going competition and in light of the short duration of an athlete's career. ${ }^{135}$ In particular, the BGH and the SFT have mentioned the need for speed as an adequate rationale for CAS arbitration. ${ }^{136}$ Whether the CAS can be consid-

le sentiment qu'elle se trouve sous la coupe du CIO." A. \& B. v. Comité International Olympique, Fédération Internationale de Ski and Tribunal Arbitral du Sport, SFT Case 4P. 267/2002, Judgment of 27 May 2003, para. 3.3.3.3. Similarly, in its Pechstein decision, the BGH referred to Germany's signing of the Convention in its balancing exercise, see BGH, supra note 2, paras 59f.

132 See Rigozzi and Robert-Tissot, supra note 72, 68.

133 The identification of the CAS as an efficient venue to deal with sporting dispute is a very widespread view in the literature. See for some examples: Gubi, supra note 95,1016-1017; Reilly, supra note 21, 81; Blackshaw, I. (2003), "The Court of Arbitration for Sport: An International Forum for Settling Disputes Effectively 'Within the Family of Sport', Entertainment Law 2(2), 61-83, 82; Findlay, H.A. (2005), "Rules of a Sport Specific Arbitration Process as an Instrument of Policy Making", Marquette Sports Law Review 16(1), 73-98, 74-76.

134 Faylor, supra note 66, 163-172. See also Nafziger, J.A.R. (2002), "Dispute Resolution in the Arena of International Sports Competition?", The American Journal of Comparative Law 50(3), 161-179, 172-177.

135 Netzle, supra note 32, 45-58.

136 The SFT held that "Il n'est pas certain que d'autres solutions existent, qui soient susceptibles de remplacer une institution à même de résoudre rapidement et de manière peu coûteuse des litiges internationaux dans le domaine du sport”. A. \& B. v. Comité International Olympique, Fédération Internationale de Ski and Tribunal Arbitral du Sport, supra note 131, para. 3.3.3.3. The BGH considered in its Pechstein ruling that "[ $\mathrm{t}]$ he further advantages of international sports arbitration compared to the state courts also include [...] the speed in making decisions which is of particular importance with regard to scheduled sports events [...]" BGH, supra note 2, para. 59. 
ered a cheap and quick judicial venue is a contested matter. In many instances, for example in doping cases, its costs are not necessarily lower than those incurred in front of national courts. ${ }^{137}$ Furthermore, due to a fast-growing caseload, its celerity in deciding cases is not as pronounced as it once was. The recourse to ad-hoc mechanisms for international competitions (e.g. the Olympic Games or the FIFA World Cup), however, does offer the advantage of on-the-spot justice. Yet, could such a "utilitarian" foundation of the CAS truly replace free consent? This would imply that the sheer quantitative economy of justice, its cost and swiftness, would trump its qualitative component. It would also be blind to the fact that judges, or their alter-ego CAS arbitrators, are in the business of allocating economic and social opportunities and making distributive calls that are not automatic and contain a strong normative core. ${ }^{138}$ Two parties might be allowed to decide freely to entrust the resolution of a private dispute (not affecting the public interest), and thus to make these distributive calls, to an arbitral panel of their liking. However, it would be abusive if one party, thanks to its monopolistic position, were allowed to decide unilaterally to do so. Hence, the fact that a mode of resolution of disputes is fast and cheap cannot be sufficient to justify the binding recourse to it. To be fair, the CAS's binding jurisdiction is almost never justified exclusively in those terms. Instead, the efficiency of CAS is often invoked in conjunction with its proximity to the sporting ethos and mind-set.

\section{In the name of... proximity}

A Swiss scholar, Gabrielle Kaufmann-Kohler, once qualified the CAS as a justice of proximity (justice de proximité). ${ }^{139}$ She meant that the CAS, and in particular its arbitrators, was close to the social reality, the people and actions, it was supposed to rule over. In other words, the CAS is embedded in the global sporting community and best placed to solve the disputes arising between its members. In this perspective, it is not the quantitative

137 On the restrictive effect of the cost of CAS arbitration on access to justice for athletes, see Rigozzi and Robert-Tissot, supra note 72, 73-81.

138 For a discussion of the inevitable politicisation of private law constructs with regard to the lex mercatoria, see Zumbansen, P. (2003), "Lex mercatoria: Zum Geltungsanspruch transnationalen Rechts", Rabels Zeitschrift für ausländisches und internationales Privatrecht 67(4), 637-682.

139 Kaufmann-Kohler, G. (1998), "Nagano et l'arbitrage - ou vers une justice de proximité, ASA Bulletin 16(2), 311-324. 
efficiency, speed and cost of CAS arbitration that is put forward, but its qualitative functional edge over territorially enshrined courts. In a way, it is building on the famous words of Lord Denning in the Enderby Town Football Club Ltd v. Football Association Ltd. case: "justice can often be done [...] better by a good layman than by a bad lawyer" ${ }^{140}$. In other words, "it may be doubted that ordinary judges are best suited to deal with specialized areas of sports discipline" 141 . Similarly, it is argued "national judges seldom have the opportunity to apply these regulations and thus may not always understand the ratio and spirit behind them" ${ }^{142}$.

A more theoretical form of the same argument would identify the CAS as the natural tribunal of a lex sportiva, a transnational private legal system/ order/regime of sport. ${ }^{143}$ Its jurisdiction would stem from its institutional function inside the system. ${ }^{144}$ From this point of view, "the very globalization of the sports movement and its high degree of cohesion, even to the point of recognizing the existence of an autonomous legal order, seem to justify a system of dispute resolution in support of this autonomy"145. By becoming the bouche de la lex sportiva, a CAS arbitrator metamorphoses into a judge embedded in a particular transnational community. ${ }^{146}$

He contributes primarily to the "consolidation" 147 and "coherence" 148 of the lex sportiva and no longer to the resolution of strictly individual disputes. In system-theoretical terms, the CAS is stabilizing the normative

140 Enderby Town FC v. the FA [1971] Ch 591, 605.

141 Paulsson, supra note 23, 361.

142 Steingruber, supra note 76, 67-70.

143 "Il n'est pas seulement l'organe chargé, selon la volonté commune des parties, de trancher leur différend; il est, au-delà la juridiction de tout un système." Latty, supra note 8, 288.

144 Maisonneuve, supra note 7; Latty, supra note 8, 288; Paulsson, J. (2010), “'Arbitration in three dimension”, LSE Legal Studies Working Paper (2), 1-34, 24-25, available at http://papers.ssrn.com/sol3/papers.cfm?abstract_id=1536093, accessed 1 February 2017.

145 Steingruber, supra note 76, 68.

146 "Le passage de l'arbitre au juge est consacré lorsque le tiers s'exprime non plus au nom des parties, mais pour le compte d'une communauté plus largement comprise." Stone-Sweet, A. and Grisel, F. (2009), "L'Arbitrage International : Du Contrat Dyadique au Système Normatif", Archives de philosophie du droit 52, 75-95, 86.

147 See, in general, the excellent chapter on the function of the CAS in the lex sportiva in Latty, supra note 8, 257.

148 Ibid., 261. 
expectations in the system of global sport. ${ }^{149}$ This is done, for example, through the development of a relatively stable jurisprudence. ${ }^{150}$ The CAS becomes the judicial institution of a specific (private) transnational regime in whose name it acts. ${ }^{151}$ The parallel is drawn with national legal orders and the forced nature of CAS arbitration is then a function of the fact that an individual is acting as a citizen/member of a specific transnational legal regime/system/order harbouring a particular functional rationality.

Can the binding jurisdiction of the CAS stem solely from it pertaining to a transnational regime/system/order regulating a specific sphere of world society? Is the pursuit of a functional rationality enough to support the CAS' forced jurisdiction? What if this functional rationality is contrary to other fundamental values (say for example the freedom to work)? The potential risk is that the "specific focus of an international court can easily lead to a strong orientation toward the 'regime interest' at the expense of other principles" 152 . An emphasis on the need for equality of athletes before the law tames this isolationist and functionalist perspective.

\section{In the name of... equality}

Finally, the mandatory jurisdiction of the CAS might stem from the need for equality in front of the (global) law. Synthetically, the much-rehearsed argument goes like this: if athletes are competing against each other on a singular global playing field, equality calls for any dispute resulting from these (global) competitions to be dealt with by a singular (global) court. ${ }^{153}$ If not, this could lead to discrepancies of interpretation and nationalistic

149 This is a reference to Niklas Luhmann's theory of law. See also, for an identical analogy, Von Bogdandy and Venzke, supra note 116, 54.

150 "Au vu de la pratique du T.A.S., l'existence d'une jurisprudence arbitrale sportive est aujourd'hui un fait indiscutable. En ce sens, le Tribunal arbitral du sport détient un pouvoir 'prétorien' indéniable.' Latty, supra note 8, 300. See also supra references in note 7 .

151 On international courts as institutional actors of a specific regime, see Von Bogdandy and Venzke, supra note 116, 68-69.

152 Von Bogdandy and Venzke (2014), supra note 1, 97.

153 In other words: "Gerade bei internationalen Wettkämpfen ist jedoch das öffentliche Interesse besonders groß und damit einhergehend auch das Bedürfnis der Athleten nach entsprechender Chancengleichheit.” Brandner and Kläger, supra note 103, 115-116. 
favour. ${ }^{154}$ From this point of view, one needs to preserve "a certain equality of treatment of athletes across borders" 155 . Thus, "the prospect of different national courts reaching inconsistent conclusions on the merits of Olympic and international sports disputes is a significant problem" 156 . Indeed, it ought to be "self-evident that international competition must be subject to a unitary international regime, lest national authorities yield to the temptation of indulgence for their own champions, thus leading to an uneven international playing field and, in some places, a race to the bottom"157. Hence, "[i]t is indispensable that all international competitors adhere to common rules, including reference to the same neutral mechanism for resolving disputes" 158 .

Some national courts have endorsed this view. The SFT held for example that "an international development towards the CAS jurisdiction in doping matters is to be upheld with a view to ensuring compliance with international standards in this field" 159 . Similarly, the OLG München in its Pechstein ruling considered that "a uniform competence and procedure can preclude that similar cases be decided differently, and therefore safeguard the equal opportunities of athletes during the competitions" ${ }^{160}$. The $\mathrm{BGH}$ in its Pechstein decision also emphasized at numerous times the benefits of a unified sporting justice. ${ }^{161}$ The underlying pragmatic logic is simple; "in order to be able to compare sports performances internationally, competitive sport must be performed in accordance with the same and uniform rules"162. However, "the risk to consistency increases with the number of fora before state courts and-as a consequence thereof-of national legal standards that apply"163. Thus, if "sport wishes to preserve its

154 This argument is raised by a plethora of authors. See, amongst many others: Haas, supra note 92, 722; Paulsson, supra note 23, 361; Steingruber, supra note 76, 70; McLaren, supra note 19, 381; Findlay, supra note 133, 96; McLaren, R.H. (2001), "Sports Law Arbitration by CAS: is it the Same as International Arbitration?", Pepperdine Law Review 29(1), 101-114, 102-103; Mitten and Opie, supra note 18, 284-285; Pfeiffer, supra note 92, 165.

155 Steingruber, supra note 76, 69.

156 Mitten and Opie, supra note 18, 284.

157 Paulsson, J. (2013), "Why Good Arbitration Cannot Compensate for Bad Courts", Journal of International Arbitration 30(4), 345-359, 357.

158 Ibid.

159 A. v. World Anti-Doping Agency (WADA), Fédération International de Football Association (FIFA) \& Cyprus Football Association (CFA), supra note 46, para. 3.3.1.

160 OLG München, supra note 98, 43 (our translation).

161 See BGH, supra note 2, paras 59ff.

162 Haas, supra note 77, 53.

163 Ibid. 
global character and the principle of uniformity this is only possible by concentrating jurisdiction at a single forum in the form of arbitration"164. The emphasis of the argument is less about a specific sporting rationality enshrined in a particular system and more about the equality of global citizens in front of the law. It points out that in a transnational context, in which people of different countries are predominantly active on a common playing field constituted by a set of transnational rules, that only a single (global) court can warrant the equality of the participants. The significant difference with the proximity justification is that it does not focus exclusively on the specificity of sport, or its particular rationality, but on the need for common justice in a transnationalized social context.

This justice can, and in fact should, embrace fundamental values transcending the sporting rationale and including, for example, fundamental human rights enshrined in the ECHR.

The efficiency, proximity and equality justifications are often unconsciously bundled together in the literature and constitute the multifarious foundations of forced CAS arbitration recognized by national courts. Yet, once disentangled, one can clearly see that the first two are merely subservient to the latter. It is the call for equality between citizens engaging in a transnationalized field of human activity that ultimately convinces the courts that a forced CAS arbitration agreement must be deemed valid. This is an un-confessed acknowledgment that the CAS is exercising muchneeded international public authority. Yet, with public authority should also come democratic legitimacy.

\section{Conclusion: Democratize the CAS!}

The CAS is definitely not speaking in the name of Claudia Pechstein. She never had a chance to commit freely to its jurisdiction. ${ }^{165}$ Does this mean that the CAS should not have jurisdiction to decide her case as some ${ }^{166}$ are suggesting? Probably not. Strong post- consensual (and post-national) rationales support the exclusive and mandatory jurisdiction of the CAS. Those potential Ersatz-names undersigning its jurisdiction are: efficiency,

164 Ibid.

165 Though one may argue that by submitting an appeal to the CAS and not challenging its jurisdiction she might have implicitly consented to it. This would be, as pointed out by the OLG, misreading the factual constraints that forced her in practice to take her chance at the CAS.

166 Heermann, supra note 102. 
proximity and especially equality. Taken together, these constitute credible post-consensual foundations for the CAS, and are recognized as such by, for example, the highest German and Swiss courts.

The globalization of sport has, to paraphrase Gunther Teubner ${ }^{167}$, broken the traditional frames of international arbitration and has led to the binding global jurisdiction of the CAS in many sporting disputes. In countless ways, it seems that the "facts on the ground are ahead of the theory" 168 . In this context, an excessive reference to consent might veil "the role of private law categories in the restructuring of post-national government" 169 . Thus, the contribution of private law "to the coagulation of sovereignty into new institutions with many state-like features remains all too often in the shade" ${ }^{170}$. The crisis of the consensual foundations of CAS arbitration unleashed by the Pechstein case brings these underlying political realities to the fore. The consensual myth was very useful "to accelerate the formation of highly political global institutions" 171 , but holding onto it "unduly stifles political debate, and may mask profound redistributive implications" 172 .

In their book, von Bogdandy and Venzke identify a similar dynamic at play in international law at large. International courts, which were traditionally seen as speaking in the name of the states, see their consensual foundations being eroded. ${ }^{173}$ However, in general, consensual underpinnings remain a stronger basis for international courts than for the CAS. Still, this progressive shift away from state consent should, in their view, entail a democratization of international courts as " $[\mathrm{n}] \mathrm{o}$ road leads past developing the democratic principle for international institutions"174. In

167 Teubner, G. (2002), "Breaking Frames: Economic Globalisation and the Emergence of lex mercatoria”, European Journal of Social Theory 5(2), 199-217.

168 Paulsson, supra note 144, 26.

169 Caruso, D. (2006), "Private Law and State-Making in the Age of Globalization", New York University Journal of International Law and Politics 39(1), 1-74, 23.

170 Ibid.

171 Ibid., 77.

172 Ibid., 79.

173 In their words: "We do not deny that the consensus of the states continues to constitute an important resource of legitimacy; however, it alone no longer sufficiently sustains many of the decisions made in recent decades." Von Bogdandy and Venzke (2014), supra note 1, 3. See also Werner, W.G. (2016), "State consent as foundational myth" In: C. Brölmann and Y. Radi (eds), Research Handbook on the Theory and Practice of International Lawmaking. Cheltenham: Edward Elgar, 13-31.

174 Von Bogdandy and Venzke (2014), supra note 1, 98. 
this regard, "[i]ndependence, impartiality, and legal expertise of the judges are not only requirements under the rule of law, but are also democratic necessities" ${ }^{175}$. This would require, in particular, ensuring the independence of judges ${ }^{176}$ and the fairness and openness of the judicial process. ${ }^{177}$

Likewise, the post-consensual nature of its jurisdiction implies that a democratic lens should be applied to the CAS. Thus, the fairness of its procedures and the independence of its arbitrators must be assessed differently, and more strictly, than under traditional (consensual) international arbitration. ${ }^{178}$ A lesser emphasis should be put on the parties to the arbitration and their consent to a particular procedural set-up and greater stress should rest on the respect of the procedural standards applied to other international and national courts, for example those enshrined in Article 6 (1) ECHR. ${ }^{179}$ The CAS being embedded in a particular transnational legal regime/system/order, it is paramount that it be institutionally separated from the political authorities (the SGBs) of that same regime/system/order. In particular, the diversity of the people affected by CAS decisions must ideally be reflected in the selection process of the CAS arbitrators.

Here lies the point of re-entry for national courts. Their contribution to the democratization of the exercise of public authority by the CAS in the transnational realm will depend on the intensity with which they decide to supervise its procedural fairness. Contrary to the LG, the approach of the OLG in the Pechstein case is a paramount example of a reflexive control aimed at triggering a democratization process of the CAS. It is akin to a Solange position: the CAS should be allowed to operate even in the absence of a consensual foundation as long as it is truly independent from the SGBs. ${ }^{180}$ In that regard, the latest decision of the BGH is a missed opportunity. The national court failed to understand its constitutional role and to properly check the democratic quality of the CAS. ${ }^{181}$

175 Ibid., 159.

176 Ibid., 158-170.

177 Ibid., 170-176.

178 See for a different theoretical path to a similar conclusion, Schultz, T. (2011), "The Concept of Law in Transnational Arbitral Legal Orders and some of its Consequences", Journal of International Dispute Settlement 2(1), 59-85.

179 A necessity recognized by Frumer, supra note 95.

180 For an elaboration of this idea in the context of EU law, see Duval, A. (2015), "The Court of Arbitration for Sport and EU Law: Chronicle of an encounter", Maastricht Journal of European and Comparative Law 22(2), 224-255.

181 For a critique of the decision from this perspective, see Duval, A. (2016), "The Pechstein case: Transnational constitutionalism in inaction at the Bundesgerichtshof”, Verfassungsblog, 10 June, available at http://verfassungsblog.de/the-pechstei 
In a rapidly transnationalizing world, where private law constructs serve as a launchpad for much-needed transnational governance systems/ regimes/orders, it is imperative that national (and regional) courts assume a new crucial constitutional function. ${ }^{182}$ They ought to exercise a reflexive, but critical, review of the transnational private regulations and institutions that are born out of unbound private power. ${ }^{183}$ Undoubtedly, "[i]f it is perceived that the important functions of control and enforcement are no longer carried out properly by the judiciary, the arbitral process may easily be manipulated for corrupt ends"184. In that regard, the OLG München's Pechstein ruling called for a necessary reform of the CAS. ${ }^{185}$ There is certainly no need for "radical" 186 or utopian solutions, such as the creation of an International Sports Court by the states, but pragmatic fixes are in order to ensure that the CAS as an institution is not captured by the SGBs. Many proposals come to mind and here is not the right place to address them comprehensively. ${ }^{187}$ Yet, one thing is certain, critically engaging with the CAS through a democratic lens has become more necessary than ever.

n-case-transnational-constitutionalism-in-inaction-at-the-bundesgerichtshof/, accessed 1 February 2017.

182 Ibid.

183 For a similar argument, see Benvenisti, E. and Downs, G.W. (2011), "National Courts Review of Transnational Private Regulation”, 1-18, available at http://ssrn. com/abstract=1742452, accessed 1February 2017.

184 Paulsson, supra note 157, 352.

185 A reform also advocated previously in the literature, see Zen-Ruffinen, P. (2012), "La nécessaire réforme du Tribunal Arbitral du Sport" In: A. Rigozzi et al. (eds), Citius, Altius, Fortius, Mélanges en l'honneur de Denis Oswald. Basel: Helbing Lichtenhahn, 483-537. See also Downie, R. (2011), "Improving the performance of sport's ultimate umpire: Reforming the governance of the Court of Arbitration for Sport”, Melbourne Journal of International Law 12(2), 67-96. And most recently by Frumer, supra note 95, 831-834.

186 On this I share the view of Veuthey, A. (2013), "Re-questioning the independence of the Court of Arbitration for Sport in light of the scope of its review", International Sports Law Review 13(4), 105-115, 114.

187 For some proposals, see Muresan and Korff, supra note 96, 208-211. See also Duval, A. (2015), "Three pillars for a reform of the Court of Arbitration for Sport: Independence, Transparency and Access to Justice”, Play The Game, 4 December, available at http://www.playthegame.org/news/comments/2015/019_t hree-pillars-for-a-reform-of-the-court-of-arbitration-for-sport-independence-transp arency-and-access-to-justice/, accessed 1 February 2017. And most recently Valloni, L. (2016), "CAS Structure and Procedure - It is now Time for a Change!", Football Legal, 36-44. 
